\title{
ОСОБЛИВОСТІ ОРГАНІЗАЦІї РОБОТИ ДІЛЬНИЧНОЇ МЕДИЧНОЇ СЕСТРИ 3 ПРОФІЛАКТИКИ ТА ЛІКУВАННЯ ГІПЕРТОНІЧНОЇ ХВОРОБИ
}

\author{
Н. Є. Боцюк, К. В. Тіхонова \\ ДВНЗ «Тернопільський державний медичний університет \\ імені I. Я. Горбачевського МОЗ Украйни"
}

\begin{abstract}
У статті висвітлено особливості роботи дільничної медичної сестри, ії обов'язки та завдання, зроблено висновок про їі роль у лікуванні та профілактиці гіпертонічної хвороби на дільниці та в поліклініці.
\end{abstract}

\section{FEATURES OF THE ORGANIZATION OF THE DISTRICT NURSE FOR THE PREVENTION AND TREATMENT OF HYPERTENSION}

\author{
N. Ye. Botsiuk, K. V. Tikhonova \\ SHEI «Ternopil State Medical University by I. Ya. Horbachevsky of MPH of Ukraine»
}

The article highlights the features of the district nurse, her responsibilities and tasks and concludes its role in the work on the station and in the clinic.

Вступ. Реформування системи охорони здоров'я в Укра ні вимагає активного розвитку інституту медсестринства. Сестринський процес $\epsilon$ універсальною технологією сестринсько справи і він повинен бути використаний дільничними медичними сестрами в сво й трудовій діяльності для своєчасного виявлення та усунення факторів ризику гіпертонічно хвороби з метою зниження рівня захворюваності та зменшення кількості ускладнень з метою підвищити якість життя пацієнтів.

Комунальний заклад «Центр первинно медико-санітарно допомоги", амбулаторія загально практики - сімейно медицини № 4 м. Кіровограда - це багатопрофільний лікувально-профілактичний заклад, покликаний надавати медичну допомогу населенню віком 18 років і старше на догоспітальному етапі та здійснювати заходи з оздоровлення населення. Режим роботи поліклініки встановлює місцевий орган влади, на територі якого розташовується медичний заклад, при цьому виходять з можливості населення відвідувати поліклініку у вільний від роботи час. Організація лікарсько дільниці створює сприятливі умови для ефективно лікувально-профілактично роботи.

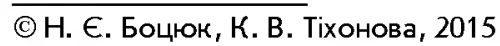

Дільничний лікар має можливість знати не тільки хворого, але і його сім'ю, протягом тривалого часу в динаміці стежити за станом здоров'я проживаючих на дільниці, розглядати захворюваність у зв'язку з конкретними умовами праці та побуту, що необхідно для здійснення лікувально-оздоровчих заходів. Дільниця сформована з урахуванням нормативів чисельності населення на ділянку. Дільничний терапевт проводить прийом хворих у поліклініці, відвідує $\mathrm{x}$ вдома за викликами чи з власно ініціативи, забезпечує диспансерне спостереження за контингентом, що його потребує, здійснює експертизу працездатності. Допомагає дільничному терапевту дільнична медична сестра. завданням $є$ не тільки допомога пацієнтам у поліклініці, а й лікування та моральна підтримка хворих на дільниці [1].

Штати дільничних медичних сестер встановлюються з розрахунку 1,5 посади на кожну посаду дільничного терапевта (наказ МОЗ Украни № 33 від 23.02.2000 р.). Працюючи під безпосереднім керівництвом і контролем дільничного лікаря і старшо медично сестри, дільнична медична сестра виконує такі види робіт:

- надання лікувально допомоги, виконання лікарських призначень хворим у поліклініці та вдома; 
- організація прийому хворих до лікаря залежно від стану х здоров'я;

- вимірювання АТ, проведення термометрі та інших маніпуляцій;

- заповнення під контролем лікаря карти амбулаторного хворого, бланка екстреного повідомлення, направлення хворого на лікувальні процедури та діагностичні обстеження;

- ведення картотеки диспансерних хворих (контрольні карти диспансерного спостереження, облікова форма № 030);

- внесення в медичну карту хворого результатів флюорографі, ЕКГ, лабораторних досліджень;

- допомога лікарю у заповненні посильних листів на МСЕК, санаторно-курортних карт, виписок з карт амбулаторних хворих;

- виписування рецептів на ліки, заповнення певних граф листка непрацездатності, медично карти амбулаторного хворого; видача талонів хворим для повторного відвідування лікаря;

- підготовка хворого до лабораторних та інструментальних досліджень;

- допомога у госпіталізаці хворих;

- комплектування сумки дільничного лікаря для надання невідкладно допомоги під час амбулаторного прийому і вдома.

У разі надання медично допомоги хворому вдома дільнична медична сестра проводить таку роботу:

- відвідування хворого і виконання призначених лікарем маніпуляцій;

- комплектування відповідним набором медикаментів, перев'язувального матеріалу та інструментами спеціально сумки для надання допомоги хворому вдома;

- інформування лікаря про виконання призначених лабораторно-інструментальних досліджень;

- організація догляду за самотніми хворими та інвалідами;

- виконання профілактичних щеплень [2].

Відвідуючи хворих вдома, дільнична медична сестра ознайомлюється з санітарним станом будинку, квартири хворого, проводить з хворим і оточуючими його особами бесіди на санітарні теми, дає поради по догляду за хворими, гігієнічний стан житла, щодо особисто гігієни, пояснює значення дотримання хворим запропонованого йому лікарем режиму [3].

Кількість дорослого населення на територі обслуговування амбулаторі становить 23802 осіб. Зацікавившись статистикою захворюваності пацієнтів, ми з'ясували, що перше місце займають хвороби серцево-судинно системи. Стосов- но дільниці № 3, чисельність яко становить 1686 осіб дорослого населення, то найбільший відсоток складають хворі саме з серцево-судинними захворювання. Застосування новітніх методів обстеження якраз і сприяли виявленню захворювання на ранніх стадіях розвитку, прогнозування мозкових інсультів особам, які вперше звернулися в поліклініку в поточному році. Із всього населення на даній дільниці 536 осіб сто ть на диспансерному обліку з хворобами серцево-судинно системи, з них - 201 з гіпертонічною хворобою (ГХ).

Саме тому метою нашого наукового пошуку було дослідження статистичних даних із серцево-судинно патологі, проведення анкетування хворих, та обґрунтування для дільничних медичних сестер індивідуальних заходів профілактики ГХ на амбулаторно-поліклінічному етапі [5]. У межах визначених завдань при ГХ медичні сестри повинні формувати у пацієнтів прихильність до лікування, а саме проводити навчальні бесіди 3 пацієнтом і його близькими, забезпечувати пацієнта пам'ятками та іншими джерелами інформаці, навчати правил користування препаратами, проводити навчальні семінари з групами пацієнтів у спеціально організованих школах здоров'я.

Вже під час першо бесіди з пацієнтом дільнична медична сестра наголошує на існуванні факторів ризику, окреслює коло проблем, обговорює план подальшо роботи. Завдання для медпрацівника - зробити хворого співучасником процесу відновлення власного здоров'я. У разі неможливості відвідування пацієнтом амбулаторно-поліклінічного відділення, бесіди та медична допомога надаються на дому. Після проведення спеціального опитування на дільниці, з'ясувалось, що значна кількість населення дільниці скаржиться на епізоди підвищення АТ, але не звертається до лікаря. При патронажі цих пацієнтів було опитано, проведено роз'яснення про важливість раннього діагностування ГХ, а також ці пацієнти запрошувались на прийом до лікаря. У поліклініці пацієнтам пояснювалась важливість проходження огляду вузькими спеціалістами, а також проведення лабораторного обстеження. Хворі були оглянуті вузькими спеціалістами: кардіологом, невропатологом, хірургом, окулістом. х було направлено на клініко-лабораторні аналізи, ЕКГ, ЕхоКС.

3 метою формування прихильності до лікування АГ на дільниці і на прийомі медична сестра повинна налаштувати пацієнта на активну співпрацю з нею та лікарем, проводити бесіди з профілактики тих чи інших захворювань. При- 
кладом тем для бесід є: «Артеріальна гіпертензія та ускладнення», “Попередження артеріально гіпертензі » [6] і «Про шкоду алкоголізму та наркомані », «Про основи здорового харчування».

При проведенні нами анкетування у респондентів виявлено дефіцит знань та інформаці :

- про спосіб життя;

- про дотримання дієти;

- про правила приймання ліків при ГХ [6];

- про правила поведінки при гіпертонічному кризі;

- про диспансерне спостереження та відповідальність щодо дотримання рекомендацій лікаря та дільнично медсестри.

Проведене дослідження виявило, що значна частина населення амбулаторно дільниці не достатньо поінформована про методи профілактики ГХ - 34,5\%, 46,8 \% обстежених не вважають за необхідне проходити диспансерне обстеження 3 приводу ГХ, 15,3 \% пацієнтів, обстежених у терапевта, порушують режим, призначену дієту і правила приймання призначених препаратів; серед обстежених жінки більш відповідально ставляться до свого здоров'я (серед них 67,8 \% знають про свою хворобу (чоловіки, відповідно, 57,3 \%), постійно приймають ліки 51,6 \% (чол. - 27,6 \%), 24,7 \% виконують основну частину рекомендацій з профілактики (чол. - 6,3\%).

Донедавна пацієнти отримували рекомендаці в основному від дільничного лікаря, медичні сестри рідко брали участь у проведенні профілактичних заходів. На нашу думку, що при виконанні свох обов'язків належним чином та проведенні в повному обсязі диспансеризаці, дільнична медична сестра може знизити рівень захворюваності та навіть смертності серед населення.

Брак інформаці $\epsilon$ потенційно небезпечним для здоров'я і життя пацієнта, тому що ГХ властиве прогресування та розвиток ускладнень аж до загрозливих для життя. Отже, хворому та його родичам необхідна повна інформація про методи лікування та профілактики ГХ. Особиста робота медсестри з пацієнтами базується найперше на взаємній довірі. Уважність та доброзичливість медично сестри має найбільше значення для налагодження спілкування з хворим. Звичайно, насамперед має значення обізнаність у даній галузі, уміння спокійно, правильно і швидко зрозуміти хворого, пройнятись його проблемами, хворобами і обрати таку тактику поведінки, яка забезпечувала б найбільш швидке і повне одужання пацієнта та віддалення рецидивів, покращення якості життя в цілому.

Висновок. Назріло питання всезагального визнання значно ролі дільнично медично сестри в поліклініці. Вона $\epsilon$ безпосередньою помічницею дільничного лікаря у його роботі серед населення дільниці, організатором умов щодо підтримання та відновлення здоров'я пацієнта, його консультантом наставником і другом. Саме медсестринський процес здатний підняти на новий рівень прихильність пацієнтів до лікування ГХ та поліпшити якість $\mathrm{X}$ життя. Тактика дільнично медично сестри в зниженні частоти захворювання на артеріальну гіпертензію - це індивідуальні бесіди з хворими та $\mathrm{x}$ родичами, широкі профілактичні заходи щодо попередження та зниження захворюваності.

4. Діяльність дільничної медичної сестри [Електронний ресурс]. - Режим доступу : [ http:// www.medn.ru/statyi/Deyatelnostuchastkovojmed.html ]

5. Артеріальна гіпертонія: сучасні діагностичні та лікувальні підходи / Л. М. Антоненко і співавт. - Львів, 1994. - 28 c.

6. Актуальні питання діагностики та лікування артеріальної гіпертоніі // Клінічна фрармакологія, фізіологія, біохімія. - 1997. - № 2. - 306 с. 